\section{CPS-036 APREMILAST ADHERENCE IN PATIENTS WITH PSORIASIS AND PSORIATIC ARTHRITIS}

${ }^{1} X$ Fernández-Sala, ${ }^{1} E$ González-Colominas, ${ }^{1} E$ Navarrete Rouco*, ${ }^{1} 0$ Ferrández, ${ }^{1} \mathrm{~N}$ Carballo, ${ }^{1} \mathrm{R}$ Gonzalez, ${ }^{1} \mathrm{~L}$ Tarrasón, ${ }^{2} \mathrm{E}$ Beltrán, ${ }^{3} \mathrm{~F}$ Gallardo, ${ }^{3} \mathrm{M}$ Ferran, ${ }^{1} \mathrm{~S}$ Grau. ${ }^{1}$ Hospital del Mar, Pharmacy Department, Barcelona, Spain; ${ }^{2}$ Hospital del Mar, Rheumatology Department, Barcelona, Spain; ${ }^{3}$ Hospital del Mar, Dermatology Department, Barcelona, Spain

\subsection{6/ejhpharm-2019-eahpconf. 185}

Background A limited number of studies have evaluated medication adherence in psoriasis (PS) or psoriatic arthritis (PsA), reporting rates between $29 \%$ and $88 \%$ (medication possession ratio (MPR >80\%)). However, until now no study has included apremilast as the evaluated drug.

Purpose To evaluate adherence to apremilast treatment in patients with $\mathrm{PsO}$ and PsA, and to assess the possible factors associated with a MPR $<100 \%$.

Material and methods Retrospective observational study including all patients beginning apremilast in an outpatient pharmacy service from a tertiary university hospital. Exclusion criteria: patients with less than one medication pharmacy refill (early discontinuation or recent treatment initiation).

Data collected demographics, treatment indication, previous biological treatment, incidence of adverse events (AE) and adherence to apremilast using the MPR.

Differences between patients with a MPR $\geq 100 \%$ vs. MPR $<100 \%$ were evaluated in the univariate analysis.

Results Forty-one patients were included: 47 (23-68) years; male 56.1\%; PsA 70.7\%; and previous biologic therapy $26.8 \%$. At least one adverse effect was reported in nine (21.9\%) patients. Thirteen (31.7\%) patients discontinued apremilast because of none-response, three (7.3\%) for adverse events and one (2.4\%) for loss of follow-up.

Adherence was: MPR 100\% in 22 (53.7\%), MPR 90\%$99 \%$ in 11 (26.8\%), MPR 80\%-89\% in four (9.8\%), MPR $70 \%-79 \%$ in two (4.9\%) and MPR $<70 \%$ in two $(4.9 \%)$ patients.

\begin{tabular}{llll} 
Abstract 4CPS-036 Table 1 & & & \\
\hline & $\begin{array}{l}\text { MPR<100\% } \\
(\mathrm{n}=19)\end{array}$ & $\begin{array}{l}\text { MPR-100\% } \\
(\mathrm{n}=22)\end{array}$ & $\begin{array}{l}\text { P-value } \\
\text { (Fisher) }\end{array}$ \\
\hline Age, median (range) & $44.0(30-62)$ & $51.5(23-68)$ & 0.630 \\
Age $>50$ years, $\mathrm{n}(\%)$ & $7(36.8)$ & $12(54.5)$ & 0.350 \\
Males, $\mathrm{n}(\%)$ & $12(63.2)$ & $11(50.0)$ & 0.531 \\
Psoriatic arthritis, $\mathrm{n}(\%)$ & $12(63.1)$ & $17(77.3)$ & 0.493 \\
Previous biologic therapy, $\mathrm{n}(\%)$ & $4(21.1)$ & $7(31.8)$ & 0.499 \\
Treatment discontinuation due to adverse & $2(10.5)$ & $1(4.5)$ & 0.588 \\
event, $\mathrm{n}$ (\%) & & & \\
Discontinuation (none-response), $\mathrm{n}(\%)$ & $5(26.3)$ & $8(36.4)$ & 0.524 \\
Any adverse event, $\mathrm{n}(\%)$ & $7(36.8)$ & $3(13.6)$ & 0.144 \\
Diarrhoea & $3(15.8)$ & $4(18.2)$ & 1.000 \\
Nausea & $1(5.3)$ & $1(4.5)$ & 1.000 \\
Headache & $4(21.1)$ & $1(4.5)$ & 0.164 \\
\hline
\end{tabular}

\section{Conclusion}

- Apremilast adherence rate was $>90 \%$ in more than $80 \%$ of the patients.

- Considering MPR $>80 \%$ reported in the literature, this rate was achieved in approximately $90 \%$ of patients, probably related to a multidisciplinary attention.
- The none factor was associated with a poorer adherence, however further studies including a greater number of patients are required.

\section{REFERENCES AND/OR ACKNOWLEDGEMENTS}

No conflict of interest.

\section{CPS-037 THE IMPACT OF MULTIDISCIPLINARY COLLABORATION IN OPTIMISING THE PRESCRIPTION OF ANTIBIOTICS IN A PAEDIATRIC HOSPITAL}

${ }^{1} \mathrm{H}$ Attjioui, ${ }^{2} \mathrm{~A}$ Cheikh, ${ }^{1} \mathrm{M}$ Lazrak, ${ }^{1} \mathrm{O}$ Hamdaoui, ${ }^{1} \mathrm{Z}$ Aliat, ${ }^{1} \mathrm{~S}$ Yaniss, ${ }^{1} \mathrm{~A}$ Benomar ${ }^{3} \mathrm{H}$ Mefetah, ${ }^{1} \mathrm{M}$ Bouatia*. 'Mohammed $v$ university-faculty of medicine and pharmacy of rabat, chis, rabat, morocco; ${ }^{2}$ Abulcasis University, Faculty of Pharmacy, Rabat, Morocco; ${ }^{3}$ Paediatric Hospital, Pharmacy, Rabat, Morocco

\subsection{6/ejhpharm-2019-eahpconf.186}

Background The safe prescription of antibiotics and their rational use constitute an essential link in the management of patients, in which all care actors have an important role.

Purpose To analyse the evolution of antibiotic consumption in a paediatric health establishment, and to develop strategies for optimising the prescription and rationalisation of their use.

Material and methods The analysis concerned four critical antibiotics (ceftazidime, imipenem/cilastine, vancomycin and amikacin), used in six departments of the paediatric hospital over the period from July 2016 to December 2017. The use of antibiotics was evaluated using the defined adult daily doses as a measurement standard that converts the physical quantities of drugs into a standard unit of measurement.

In order to overcome the problem of overconsumption, we have put, in collaboration with the health facility's drug committee, some strategies for optimising the prescription of antibiotics, such as the requirement of antibiogram results for prescriptions containing a critical antibiotic, discussion of the choice of antibiotic therapy to limit bacterial resistance and reinforcement of hygiene measures to reduce the incidence of nosocomial infections.

Results The results of the evolution of consumption are presented in the following table 1 in (\%):

\section{Abstract 4CPS-037 Table 1}

\begin{tabular}{lll}
\hline & Before the corrective action & $\begin{array}{l}\text { After the corrective } \\
\text { action }\end{array}$ \\
\hline Department & $\begin{array}{l}\text { Evolution of average monthly } \\
\text { consumption between last } \\
\text { semester of } 2016 \text { and first }\end{array}$ & $\begin{array}{l}\text { Evolution of average } \\
\text { monthly consumption } \\
\text { from July } 2017 \text { to }\end{array}$ \\
& semester of 2017 & $\begin{array}{l}\text { December } 2017 \\
\text { Gastroenterology department }\end{array}$ \\
Department of endocrinology & $+35 \%$ & $-53 \%$ \\
and neurology & $+30 \%$ & $-22 \%$ \\
Neonatal intensive care unit & $+15 \%$ & $-21 \%$ \\
Child intensive care unit & $+11 \%$ & $-33 \%$ \\
Infectiology department & $-17 \%$ & $-8 \%$ \\
Other departments & $+1 \%$ & $-19 \%$ \\
\hline
\end{tabular}

Conclusion The optimisation of antibiotic use through collaboration and multidisciplinary actions was observed in the results, with considerable variation across services. The success 